\title{
LOS INTERESADOS EN LOS PROCEDIMIENTOS ADMINISTRATIVOS SANCIONADORES
}

\author{
THE INTERESTED IN THE ADMINISTRATIVE PROCEDURES \\ SANCTIONS
}

\section{Rosa Fernanda Gómez GonzÁlez*}

\begin{abstract}
RESUMEN: El trabajo analiza la situación de los interesados no infractores en los procedimientos sancionadores, determinando cuáles son los objetivos que persiguen y cuáles son los mecanismos que nuestro ordenamiento dispone para la defensa y garantía de sus derechos e intereses. La investigación plantea que tratándose de interesados no infractores la aplicación supletoria del artículo 21 de la Ley No 19.880 procede en los procedimientos sancionadores previo análisis de los diversos intereses y derechos concurrentes.
\end{abstract}

Palabras clave: denunciante, denuncia, tercero, víctima, impugnación, principio de oportunidad.

\begin{abstract}
The paper analyzes the situation of the non-infringing stakeholders in the sanctioning procedures, determining the objectives and mechanisms that our legal system has for the defense and guarantee of their rights and interests. The investigation proposes that in the case of non-infringing parties, the supplementary application of article 21 of Law No. 19,880 proceeds in the sanctioning procedures after analyzing the various interests and competing rights.
\end{abstract}

Keywords: complainant, complaint, third, victim, challenge, principle of opportunity.

\section{ASPECTOS GENERALES}

En los procedimientos administrativos sancionadores, la relación jurídica procedimental se establece entre el órgano administrativo titular de la potestad punitiva (sujeto activo) y el sujeto infractor (sujeto pasivo) ${ }^{1}$, siendo el inculpado el principal interesado en el procedimiento sancionador de conformidad al artículo 21 de la Ley No 19.880. En otros términos, el procedimiento sancionador presenta una estructura predominantemente uni-

\footnotetext{
Doctora en Derecho. Investigadora y Profesora de Derecho Administrativo, Pontificia Universidad Católica de Valparaíso. Código Orcid: 0000-0003-4769-6749. Dirección postal: Avenida Brasil No 2950, Valparaíso. Dirección electrónica: rosa.gomez@pucv.cl. Esta investigación se enmarca en el Proyecto FONDECYT Postdoctoral No 3190494 "Sanciones administrativas y derechos fundamentales. Análisis de temas específicos a partir de los principios, garantías y derechos regulados en la Constitución” y del FONDECYT Regular No 1201868 "Criterios y estándares para el control de la potestad sancionadora de la Administración: análisis de los mecanismos de revisión judicial y administrativa”. Asimismo, cuenta con el apoyo del proyecto de investigación "Derecho Administrativo Sancionador 2.0" (2018-RTI-096688-B-100), Proyecto I+D+i «Retos Investigación» 2018, impulsado por el Ministerio de Ciencia, Innovación y Universidades de España y del Fondo Europeo de Desarrollo Regional (FEDER). Finalmente agradezco a mis colegas, quienes, de manera crítica, tuvieron ocasión de revisar la versión inédita de este trabajo.

1 Constituiría una situación jurídica pasiva, Moraga (2010) pp. 73 y ss.
} 
direccional con el objeto de verificar la existencia o no de una infracción administrativa y su sanción ${ }^{2}$.

Ahora bien, en esta relación jurídica pueden aparecer terceros que manifiesten tener algún interés en el procedimiento sancionatorio, sea porque han sido directamente afectados por la infracción o porque buscan el restablecimiento de la legalidad quebrantada a través de la imposición de medidas represivas al infractor responsable del ilícito ${ }^{3}$.

Frente a este escenario, surge la interrogante relativa a si dichos terceros pueden o no intervenir en el procedimiento sancionador en calidad de interesados, en cuyo caso, la siguiente cuestión será determinar en qué condiciones y en qué supuestos es posible admitir su participación. Este último aspecto resulta sumamente relevante definir la incidencia que puede tener un tercero en la instrucción del procedimiento, tramitación e inclusive en las etapas de impugnación y ejecución de las sanciones administrativas.

Para responder a estas interrogantes, se analizan las distintas normas legales aplicables, ello en armonía con los derechos y garantías que se le reconocen al infractor en el procedimiento sancionador.

\section{SOBRE LOS INTERESADOS EN EL PROCEDIMIENTO SANCIONADOR}

El artículo 21 de la Ley No 19.880 establece que son interesados en el procedimiento administrativo: 1) quienes lo promuevan como titulares de derechos o intereses individuales o colectivos; 2) los que, sin haber iniciado el procedimiento, tengan derechos que puedan resultar afectados por la decisión que en el mismo se adopte, y 3) aquellos cuyos intereses, individuales o colectivos, puedan resultar afectados por la resolución y se apersonen en el procedimiento en tanto no haya recaído resolución definitiva.

En este contexto, el sujeto infractor aparece como el principal interesado en el procedimiento sancionador, dado que el contenido del acto terminal puede afectar sus derechos, $v$. gr. una sanción de multa o la revocación de una autorización, puede afectar los derechos de propiedad o a desarrollar una actividad económica. En este sentido, se ha reconocido la supletoriedad de la Ley No 19.880 puesto que a partir de dicho texto normativo se pueden hacer valer un conjunto de derechos y garantías para el infractor como el derecho a formular alegaciones y aportar documentos, a conocer el estado de tramitación del procedimiento, a la adecuada precisión de cargos, a la presunción de inocencia y a la separación de las fases de instrucción y sanción ${ }^{4}$.

Ahora bien, en muchos casos la infracción no solo involucra a la Administración y al infractor, sino que su comisión bien puede comprometer el interés de terceros. En tal contexto, es preciso analizar el interés invocado y/o en qué elementos del procedimiento recae, esto es, sobre el expediente, el acto terminal, la sanción, las medidas que puede adoptar la Administración, etc.

\footnotetext{
2 Comunidad Indígena AtaCAMEÑa de PeINE CON SMA (2019) c. 47 o (actualmente en casación).

3 A modo de ejemplo: CRUZ PÉREZ y otros CON SMA (2014) cc. $12^{\circ}$ y ss. y AgŔ́COLA EL SOL DE Copiapó LTDA. Y OTRA CON SMA (2016) c. 3․

4 Quezada (2017) p. 152.
} 
En primer lugar, cabe descartar un "derecho a castigar", esto es, que los terceros interesados sean titulares de un derecho subjetivo que les permita exigir a la Administración la instrucción de un procedimiento sancionador y requerir, dentro de él, la aplicación de una sanción determinada o en su caso, impugnar una sanción solicitando la imposición de una medida más gravosa para el infractor ${ }^{6}$.

Distinta es la situación cuando se revisan los efectos de la infracción, los cuales podrían afectar derechos de terceros. Así, por ejemplo, una infracción que puede vulnerar el derecho a la vida y a la integridad física y síquica (artículo 19, No 1 de la Constitución (CPR)); a la igualdad (artículo 19, No 2 CPR); a vivir en un medio ambiente libre de contaminación (artículo 19, No 8 CPR); a la salud (artículo 19, No 9 CPR); a desarrollar una actividad económica (artículo 19, No 21 CPR); de propiedad (artículo 19, No 24 CPR), entre otros.

En este sentido, es preciso tener presente que a través del ejercicio de la potestad sancionadora se buscar dar protección a bienes jurídicos supraindividuales o colectivos, como sería la vida y salud de la población, el medio ambiente, el mercado financiero o la hacienda pública. Sin embargo, no se puede desconocer el hecho de que, en ciertos casos, un tercero o un grupo de ellos pueden ser afectados con la ocurrencia de una conducta ilícita, por ejemplo, los consumidores por un producto defectuoso, los vecinos de una empresa contaminante, los apoderados de un establecimiento educacional o las personas que consumen alimentos en mal estado en un restaurante, surgiendo un interés individual o general, en su caso, en que la infracción sea puesta en conocimiento de la Administración para que ésta adopte las medidas que sean necesarias para dar garantía a sus propios derechos, así como a los de otros terceros que se encuentren en idéntica situación.

En materia administrativa sancionadora las principales discusiones han tenido por objeto definir los derechos y garantías del interesado-infractor para su adecuada defensa en el procedimiento sancionador. En tal sentido, existe cierto consenso en que aquél tiene derecho a un justo y racional procedimiento y a la revisión judicial de la sanción impuesta. Sin embargo, los derechos e intereses de terceros interesados no infractores es un tema que

\footnotetext{
5 Así fue indicado en la Exposición de Motivos de la Ley No 2 de 1998, que regula la potestad sancionadora de las Administraciones Públicas de la Comunidad Autónoma del País Vasco, en donde se señaló que "El ciudadano no tiene derecho a castigar, pero en cuanto víctima posible del ilícito penal o administrativo, tiene un claro interés en solicitar el ejercicio del poder público punitivo y en participar en el procedimiento previsto para encauzar tal ejercicio.", de lo cual se desprende que es necesaria la existencia de un interés legítimo para deducir la denuncia.

En tanto, el Tribunal Supremo español ha sostenido la inexistencia del derecho de un denunciante a la incoación de un procedimiento sancionador en cuanto tal o a la imposición de una sanción. La ausencia de un interés convierte al actor en un defensor abstracto de la legalidad y, como tal, carece de legitimación para instar en vía administrativa la incoación de un expediente, por ej. SENTENCIA TRIBUNAL SUPREMO, 11 de abril de 2006, fj. $3^{\circ}$ y SENTENCIA TRIBUNAL SUPREMo, 10 de diciembre de 2010, fj. $2^{\circ}$, entre otras.

6 A nivel comparado se ha negado legitimación para solicitar la imposición de una sanción o agravar la ya impuesta, ello por cuanto aquello no produce, como regla general, efecto positivo alguno en la esfera jurídica del denunciante, ni elimina carga o gravamen alguno, en SENTENCIA TRIBUNAL SUPREMO, 28 de enero de 2019, FD $2^{\circ}$. En Chile no existe un reconocimiento general de las posiciones jurídicas subjetivas que configuran la legitimación activa para impugnar los actos administrativos, éstas son diversas y dependen de regulación específica en cada procedimiento especial, en FERrada (2013) p. 183.
} 
no presenta una mayor discusión doctrinaria ${ }^{7}$, no obstante existir un amplio reconocimiento de su rol como denunciantes.

\section{TIPOS DE INTERESADOS EN EL PROCEDIMIENTO SANCIONADOR Y SUS CARACTERÍSTICAS}

Sin perjuicio de lo dispuesto en la Ley No 19.880, en nuestro ordenamiento jurídico no existe una regulación general que se refiera al rol de los interesados no infractores en los procedimientos administrativos sancionatorios ${ }^{8}$. A nivel sectorial, es posible encontrar disposiciones que analizan ciertas intervenciones, como ocurre con la figura del denunciante, la cual aparece regulada, pero solo de forma parcial. Más allá de ello, no se hace un mayor análisis de su participación y de los alcances de aquélla, sin perjuicio de que el tema es cada día objeto de una mayor discusión legal ${ }^{9}$ y jurisprudencial ${ }^{10}$.

En materia penal, la figura del interesado se puede asimilar a la del querellante, quien tiene una reglada participación en el proceso penal. Así, el querellante dispone de un momento procesal para presentar la querella ${ }^{11}$; debe observar un conjunto de requisitos para deducirla, bajo sanción de inadmisibilidad ${ }^{12}$; está sujeto a ciertas prohibiciones ${ }^{13}$; puede desistirse de la querella en cualquier momento, entre otros. Por su parte, la víctima no querellante puede participar en el proceso conforme a un orden de prelación excluyente para su intervención en el proceso ${ }^{14}$ y de un conjunto de derechos taxativamente enumerados que puede ejercitar en el mismo ${ }^{15}$. Como se puede apreciar, se trata de una intervención acotada y sumamente regulada, supeditada por regla general a los intereses que el Ministerio Público representa.

Este nivel de regulación no se advierte en el ámbito sancionatorio. Por el contrario, se aprecia una ausencia de regulación general sobre la participación de terceros interesados.

\footnotetext{
7 Aunque es posible encontrar trabajos a nivel sectorial, por ej. HunTER (2019) pp. 173-199.

8 En España, la amplia regulación del concepto de interesado que ofrece la Ley de Procedimiento Administrativo permite la intervención de los interesados en el procedimiento sancionador, lo cual sería conforme, por una parte, con las garantías y derechos fundamentales y, por la otra, con la defensa de los intereses públicos y de los colectivos o difusos que informan el Estado social de Derecho, Rebollo (1993) p. 229.

9 Como ocurre en aquellos sectores en los cuales los terceros interesados se ven afectados de un modo más directo y concreto con los efectos de la infracción, por ej. ambiental, en donde se ha recurrido a los conceptos de "área de influencia” o "entorno adyacente" (CARRASCO CON SMA (2017) c. 11).

10 Como se verá infra, existen pronunciamientos en material ambiental, educación, eléctrico, etc.

11 Artículo 112 Código Procesal Penal.

12 Artículos 113 y 114, letra b) Código Procesal Penal.

13 Artículo 116 Código Procesal Penal.

14 Artículo 108, inciso 3o Código Procesal Penal.

15 De conformidad al artículo 109 inciso $1^{\circ}$ Código Procesal Penal, la víctima que intervenga en el procedimiento penal tendrá, entre otros, los siguientes derechos: a) solicitar medidas de protección; b) presentar querella; c) ejercer contra el imputado acciones de responsabilidad civiles provenientes ilícito; d) ser oída por el fiscal antes de que éste pidiere o se resolviere la suspensión del procedimiento o su terminación anticipada; e) ser oída, si lo solicitare, por el tribunal antes de pronunciarse acerca del sobreseimiento temporal o definitivo u otra resolución que pusiere término a la causa; y f) impugnar el sobreseimiento temporal o definitivo o la sentencia absolutoria, aun cuando no hubiere intervenido en el procedimiento.
} 
Por ello, es relevante analizar la supletoriedad de la Ley No 19.880, cuya aplicación procede en la medida que la materia a la cual se pretende emplear no haya sido prevista en la ley especial. Además, Contraloría ha señalado que la aplicación supletoria procederá en cuanto ella sea conciliable con la naturaleza del respectivo procedimiento especial, toda vez que su objetivo es solucionar los vacíos que éste presente, sin que pueda: 1) afectar o entorpecer el normal desarrollo de las etapas y mecanismos que dicho procedimiento contempla, y 2) afectar el propósito del procedimiento especial ${ }^{16}$. De ahí la necesidad de analizar la procedencia de la aplicación supletoria del artículo 21 de la Ley No 19.880 tratándose de la intervención de terceros interesados en los procedimientos sancionatorios, por lo que es relevante establecer una clasificación de los distintos tipos de terceros interesados, sus características y derechos o intereses que eventualmente pueden hacer valer en un procedimiento administrativo sancionador.

\section{LA DENUNCIA Y EL DERECHO DE PETICIÓN}

En primer término, es necesario referirse a la relación entre la denuncia y el derecho de petición consagrado en el artículo 19 No $14^{\circ}$ de la CPR. Para algunos autores la intervención de terceros en los procedimientos sancionadores luego de la denuncia sería una manifestación del derecho de petición, por lo que, sin perjuicio de las regulaciones sectoriales, no se requeriría de un respaldo normativo especial para denunciar ilícitos. Así entendida, la denuncia sería una petición que se formula a la autoridad para que corrija y sancione el hecho denunciado, pero que no habilita al denunciante a ser parte del procedimiento ${ }^{17}$.

No obstante, la denuncia no se puede entender como una expresión del derecho de petición ${ }^{18}$, por cuanto solo tiene por objeto poner en conocimiento de la autoridad ciertos hechos ${ }^{19}$, esto es, simplemente busca "informar de un hecho u omisión", lo cual es sin perjuicio de que adicionalmente el denunciante realice peticiones o solicitudes a la autoridad, pero esto ya no es parte de la denuncia, sino elementos independientes de la misma. En otros términos, en un escrito dirigido a la autoridad el tercero puede denunciar un ilícito y presentar una petición o solicitud, como sería la fiscalización de hechos, la instrucción de un procedimiento o la adopción de medidas de paralización o mitigación de los efectos de la infracción, ambas cuestiones de naturaleza diversa. En este último supuesto, la denominación más adecuada sería la de "denunciante-solicitante", ya que su actuación no se limita a la denuncia, sino que adicionalmente solicita ciertas acciones a la autoridad ${ }^{20}$.

\footnotetext{
16 Por ej., Dictamen No 15.331 , de 2018.

17 Sepúlveda y Zúñiga (2014) pp. 690-691.

18 Para la doctrina constitucional este derecho comprende la presentación de peticiones a la autoridad, constituyendo un instrumento de participación democrática, que permite a las personas presentar o hacer presente sus problemas, necesidades, sugerencias, planteamientos de interés general o requerimientos a la autoridad competente respectiva, en Nogueira (2013) Tomo II, p. 197 y Aldunate (2009) Tomo I, p. 266

19 La denuncia, en el contexto administrativo, es el acto por el que cualquier persona, en cumplimiento o no de una obligación legal, pone en conocimiento de un órgano administrativo la existencia de un determinado hecho que pudiera constituir una infracción administrativa, MuÑoz (2017) Vol. I, p. 759.

20 Gosálbez (2012) pp. 1428 y ss.
} 
Para la doctrina, en estos casos el interesado tendría un interés especial en que la Administración instruya el procedimiento y sancione al denunciado, manifestando un animus no de mera legalidad, sino de legalidad punitiva, esto es, que busca instar a que el órgano adopte las medidas necesarias para el cumplimiento de la legalidad presuntamente lesionada $^{21}$. Ello daría lugar a una especie de "procedimiento preliminar" que impondría a la Administración el deber de resolver la solicitud de iniciación planteada por el denunciante y notificarle la resolución que recaiga sobre ella ${ }^{22}$.

Sin perjuicio de que los terceros pueden presentar denuncias y plantear todo tipo de solicitudes, cabe recordar que el ejercicio de la potestad sancionadora corresponde a la Administración, siendo ésta la encargada de instruir el procedimiento y sancionar si se acredita la ocurrencia de una infracción, pudiendo, además, adoptar las medidas provisionales y accesorias que estime pertinentes, sin que le sean vinculantes las solicitudes efectuadas por los denunciantes, lo que no impide a que las pueda tener en consideración al momento de adoptar sus decisiones y tramitar el procedimiento ${ }^{23}$.

Ahora bien, de lo expuesto, se puede desprender la existencia de al menos dos tipos de terceros interesados: aquel que interviene mediante una denuncia y que solo busca el respeto de la legalidad objetiva (interesado colaborador o simple denunciante) y aquel interesado-víctima afectado directamente por la infracción y que pretende participar como interesado en el procedimiento sancionador, sea mediante la presentación de denuncia o una vez iniciando el mismo.

\section{El TERCERO INTERESADO COLABORADOR O SIMPLE DENUNCIANTE}

Corresponde a un interesado no infractor que actúa como garante de la legalidad. Se trata de un tercero interesado en el cumplimiento de la legalidad objetiva, que se encarga de informar a la Administración, a través de una denuncia, hechos u omisiones que bien pueden o no ser calificados como ilícitos administrativos, sin ostentar ninguna otra pretensión. En estos casos, la denuncia tiene por objeto alertar y/o poner en conocimiento del órgano competente circunstancias que podrían significar faltas o infracciones a normas cuyo cumplimiento debe verificar ${ }^{24}$, desplegando su actividad fiscalizadora o sancionadora si concurren los requisitos para ello ${ }^{25}$.

21 Gosálbez (2012) p. 1429.

22 Gosálbez (2012) p. 1430. Para la Sentencia Tribunal Supremo de Justicia de Cantabria, 30 de enero de 2002, la denuncia, acompañada de una solicitud de iniciación, genera un derecho al trámite, esto es, a un procedimiento preliminar que obliga a la Administración a resolver sobre la iniciación del expediente sancionador.

23 Por ej. en materia sanitaria si el sumario se inició por denuncia, la autoridad citará al posible infractor y al denunciante, y examinará separadamente a los testigos y demás medios probatorios, levantando acta de lo obrado, y se practicará las investigaciones necesarias para el esclarecimiento de los hechos denunciados (artículo 164 del Código Sanitario). Lo anterior debe ser complementado con lo dispuesto en el Manual de Fiscalización Sanitaria el que señala que el denunciante podrá aportar medios probatorios que tengan por objeto acreditar la infracción sanitaria denunciada (p. 18).

24 Dictamen No 5.853, de 2013. La denuncia constituiría, en conformidad con lo señalado en el artículo 29 de la Ley No 19.880, solo un antecedente para que eventualmente la autoridad correspondiente inicie de oficio un procedimiento administrativo.

25 Sentencia Tribunal Supremo, 7 de junio de 1985. 
En nuestro ordenamiento diversas son las disposiciones que indirectamente se refieren a este tipo de interesado al regular la denuncia. Así, el artículo 164 del Código Tributario dispone que las personas que tengan conocimiento de la comisión de infracciones tributarias podrán efectuar la denuncia ante la Dirección o Director Regional competente. Por su parte, el artículo 21 de la Ley No 20.417 señala que cualquier persona podrá denunciar el incumplimiento de instrumentos de gestión ambiental y normas ambientales. En tanto, el artículo 161 del Código Sanitario señala que los sumarios podrán iniciarse por denuncia de particulares, en similar sentido el artículo 172 bis inciso $2^{\circ}$ del Código de Aguas dispone que el procedimiento se podrá iniciar por la denuncia de un particular. Con carácter más amplio, el artículo 12 de la Ley No 18.755, que establece normas sobre el Servicio Agrícola y Ganadero, concede acción pública para denunciar los ilícitos allí señalados y el artículo 192 del Código del Trabajo concede acción popular para denunciar las infracciones al título allí referido, entre otras ${ }^{26}$.

En cuanto a las formalidades para la intervención de este tercero, se traducen en la presentación de una denuncia destinada a exigir el respeto a la legalidad, sin que sea necesario invocar la vulneración a un derecho o interés legítimo, sino solo indicar algunos datos o contenidos mínimos establecidos en las regulaciones sectoriales respectivas, tales como el lugar y fecha de presentación, la individualización completa del denunciante y, en su caso, de su mandatario o representante legal ${ }^{27}$, una descripción de los hechos concretos que se estiman constitutivos de infracción, el lugar y las referencias suficientes para determinar el lugar en que aconteció el ilícito, la fecha probable de su comisión, las normas infringidas si las conociera el denunciante, la individualización del presunto infractor, en caso de que pudiera identificarlo ${ }^{28}$, entre otros.

A priori, este tipo de tercero no busca exigir la imposición de sanciones, sean pecuniarias o de otro tipo ${ }^{29}$. Se trata de una "denuncia simple" 30 o "mera denuncia" que

\footnotetext{
26 Tratándose de intereses colectivos, la doctrina sostiene la necesidad de introducir la acción pública, ello en la medida de que dichos intereses se refieran a un grupo de personas o al conjunto de la colectividad, como sería en asuntos vinculados con el medio ambiente, en LOZANO (2003) pp. 106 y ss.

27 Con todo, quien denuncia podría solicitar a la Administración que conserve su anonimato, en este sentido GosÁlbeZ (2012) p. 1431, sostiene que la Administración puede reservar su identidad si aprecia previsibles perjuicios para el denunciante solicitante. En Chile, en materia de libre competencia el denunciante podría solicitar la reserva de su identidad. Por su parte, el Manual de Procedimiento Sancionatorio de Fiscalización de la DGA (2018) contempla la posibilidad de que el denunciante no complete alguno de los campos obligatorios del "Formulario de Requerimiento de Fiscalización" (p. 9). Sin embargo, el inculpado podría solicitar a la Administración la información relativa a la identidad del denunciante, por ej. en aquellos casos en que, con ocasión de denuncias temerarias o luego de una absolución, pretenda deducir acciones penales o civiles de indemnización de perjuicios, lo que no deja de ser problemático, puesto que podría desincentivar las denuncias anónimas.

28 Requisitos referidos en el artículo 172 bis inciso $3^{\circ}$ del Código de Aguas.

29 Sentencia TRIbunal Supremo, 28 de enero de 2019, FD 20

30 Esto es, aquel que se limita a poner en conocimiento de la autoridad unos determinados hechos, presuntamente constitutivos de infracción administrativa, en Tola (1999) p. 842.
} 
cualquier particular puede realizar ante los organismos fiscalizadores como una forma de colaboración social ${ }^{31}$.

Por su parte, la denuncia impone a Administración la carga de evaluar su pertinencia, verosimilitud y determinar si iniciará el procedimiento sancionador (artículo 29 de la Ley No 19.880) ${ }^{32}$. En efecto, una vez presentada la denuncia, deberá ser analizada por la Administración conforme a los requisitos de forma ${ }^{33}$ y a los criterios que regulan el ejercicio del poder punitivo, dentro de los cuales se encuentran la gravedad de los hechos denunciados y la necesidad de aplicar una sanción. Solo luego de que se hayan revisado los antecedentes conforme a dichos criterios, se tendrán que determinar las medidas que se adoptarán al efecto: fiscalizar, instruir un procedimiento sancionador, archivar los antecedentes, adoptar medidas o, inclusive, sancionar al denunciante temerario ${ }^{34}$. En otros términos, ante una denuncia interpuesta ante la autoridad respectiva, ésta tiene cierto margen de acción para definir si desarrolla o no determinadas actividades fiscalizadoras, como asimismo para discernir si da o no inicio a un procedimiento sancionatorio, decisión que, en todo caso, deberá ser motivada ${ }^{35}$.

Al respecto, cabe tener presente que el procedimiento administrativo sancionador siempre se instruye de oficio, pues es la Administración la que debe adoptar la decisión de iniciarlo, aun cuando exista denuncia de un tercero o de un órgano administrativo. En este sentido, cabe recordar que el artículo 16 del proyecto de ley de bases de procedimientos administrativos sancionatorios, señalaba que el procedimiento podría iniciarse de oficio o por denuncia, agregando, en sus artículos 18 y 19, los requisitos formales que debía reunir y sus efectos, precisando, en lo que interesa, que la denuncia "[...] originará un procedimien-

\footnotetext{
$31 \mathrm{Al}$ respecto, la jurisprudencia española ha sostenido que la denuncia no tiene otro efecto que el de poner en conocimiento de la Administración la comisión de hechos supuestamente ilícitos, con el fin de que se ponga en marcha su actividad investigadora o sancionadora, calificando al denunciante como un "agente de la Administración" o "testigo cualificado", desprovisto de legitimación para recurrir la desestimación de la denuncia o participar como interesado en el procedimiento sancionador, al efecto véase los pronunciamientos citados en Huergo (1995) p. 210 (nota 45) y el análisis que sobre la materia se efectúa en LozANo (2003) p. 85 (nota 4).

32 Según la doctrina, la iniciación de un procedimiento sancionatorio podrá ser facultativa o no, empero una vez que concurran ciertos elementos, normalmente vinculados a la gravedad de la conducta, su incoación deviene en obligatoria, en Cordero (2014) p. 301. Por el contrario, Bermúdez señala que en el "[...] ejercicio de potestades sancionadoras el legislador, normalmente, no entrega facultades de apreciación de la actuación, es decir, producida la infracción, ésta debe aplicar alguna de las sanciones previstas, dentro de las cuales sí existe un margen de apreciación, que se traduce en la discrecionalidad de elección”, en BERMúdez (2012) p. 7. En este sentido, estimo que la primera posición se ajusta a los argumentos sostenidos y a la realidad del ejercicio de la potestad punitiva. En la práctica, diversas entidades han procurado transparentar las circunstancias bajo las cuales la iniciación del procedimiento será facultativa u obligatoria, por ej. DICTAMEN No 17 , de 2015 , de la Superintendencia de Educación.

33 Por ejemplo, el DS No 119, de 1989, del Ministerio de Economía, que aprueba el reglamento de sanciones en materia de electricidad y combustibles, en su artículo $11^{\circ}$ establece que no se dará curso a la denuncia que no cumpla con los literales a) y b) del artículo $10^{\circ}$ del mismo cuerpo reglamentario.

34 En tal sentido, el artículo 65 de la LEY No 20.529 de 2011 dispone que "Si el Director Regional o el Superintendente, mediante resolución fundada, establecen que la denuncia carece manifiestamente de fundamentos, podrán imponer a quien la hubiere formulado una multa no inferior a 1 UTM y no superior a 10 UTM, atendida la gravedad de la infracción imputada”.

35 Dictámenes No s. 4.547, de 2015 y 75.745, 2016.
} 
to sancionatorio si a juicio del órgano u organismo competente, está revestida de seriedad y tiene mérito suficiente". En caso contrario, se podría disponer la realización de acciones de fiscalización sobre el presunto infractor y si no existiere mérito para ello, se dispondría el archivo de la misma por resolución someramente fundada, notificando de ello al interesado. Como consecuencia de la instrucción de oficio, el desistimiento de la denuncia no vincula a la Administración, la cual podrá continuar adelante con la actividad fiscalizadora o con el procedimiento sancionador conforme a los antecedentes investigados ${ }^{36}$.

A pesar de que dicho proyecto fue archivado, algunas de sus disposiciones fueron consideradas en la normativa sancionadora especial, en las que persiste la idea de que solo se podrá instruir un procedimiento sancionatorio en la medida que la denuncia sea seria y tenga mérito suficiente ${ }^{37}$. No obstante, siempre será posible dar lugar a una etapa de investigación o fiscalización que le permita a la autoridad verificar algunos antecedentes preliminares de la denuncia y así justificar el inicio formal de la investigación ${ }^{38}$.

Esta idea ha sido sostenida por la Corte Suprema en materia ambiental ${ }^{39}$ al señalar que una vez que se recibe la denuncia, ésta debe ser examinada por la Administración, quien debe realizar un análisis de aquella. Si cumple con las exigencias de seriedad y tiene mérito suficiente, se iniciará el procedimiento sancionatorio con la formulación de cargos; en cambio, si ésta no cumple con las exigencias mínimas, la desechará mediante la dictación de una resolución fundada o, si requiere información adicional, dictará actos de instrucción previa ${ }^{40}$.

En el mismo sentido, la jurisprudencia administrativa ha señalado que aquélla puede originar la instrucción de un procedimiento sancionatorio si a juicio de la Superintendencia del Medio Ambiente (SMA) está revestida de seriedad y tiene mérito suficiente, puesto que, en caso contrario, se podrá disponer previamente la realización de acciones de fiscalización sobre el presunto infractor, cuya finalidad es verificar el cumplimiento de la normativa, sin mediar la formalización de un proceso sancionador. Esto sin perjuicio de que si ni siquiera existiere mérito para ello, se ordene el archivo de la misma por resolución fundada, notificando tal decisión al interesado. Según el órgano de control, la preceptiva entrega a la SMA cierto margen de apreciación para definir si desarrolla o no determinadas actividades fiscalizadoras, como, asimismo, para discernir si da o no inicio a un procedimiento sancio-

\footnotetext{
36 Esta situación ha sido reconocida por la jurisprudencia administrativa en materia disciplinaria, al señalar que el desistimiento de todo cargo en contra del inculpado, puede considerarse tan solo una retractación de las declaraciones previamente prestadas, que no amerita, por sí misma, se declare la absolución del inculpado, máxime si se ha acreditado su responsabilidad en los hechos investigados, véase DICTÁMENES $\mathrm{N}^{\text {os }} 14.009$, de 1972 y 59.940, de 2004.

37 Por ej. artículo 55 letra c) de la LEY No 19.995 de 2005; artículo 47, inciso final, de la LEY No 20.417 de 2010; inciso 40 del artículo 172 bis del Código de Aguas; entre otros.

38 Cordero (2014) p. 298.

39 Artículo 21 de la LEY No 20.417.

40 EXPORTADORA LOS FIORDOS LIMITADA CON SMA (2017) c. 19. En tanto, los tribunales ambientales han señalado que la SMA deberá efectuar un análisis exhaustivo e integral de los hechos denunciados, de manera que la resolución que ordene archivar una denuncia debe necesariamente estar fundamentada y obedecer a un estándar de motivación sustantivo, en SEPÚLVEDA Y OTRO CON SMA (2018) c. $19^{\circ}$.
} 
natorio, decisión que, en todo caso, es exigible que tenga una motivación y un fundamento racional ${ }^{41}$.

Ahora bien, en el caso particular del sancionatorio ambiental, la ley establece que la SMA deberá informar los resultados de la denuncia en un plazo no superior a 60 días hábiles, y agrega que, si como consecuencia de ella se inicia el procedimiento sancionador, el denunciante tendrá para todos los efectos legales la calidad de interesado en el precitado procedimiento. Con todo, aun cuando no esté expresamente regulado, por razones de certeza y de buena técnica administrativa, la decisión que no dé lugar a la denuncia tendrá que ser fundada, expresarse por escrito y en términos formales ${ }^{42}$, y ser resuelta oportunamente y sin dilaciones injustificadas (artículos $3^{\circ}, 5^{\circ}$ y $8^{\circ}$ de la LOCBGAE) $)^{43}$.

En otros regímenes sancionatorios, como educación ${ }^{44}$, la Corte Suprema sostuvo que para la Ley No 19.880 el procedimiento administrativo solo puede iniciarse por dos vías: de oficio por la autoridad o a petición de parte, por lo que la denuncia no tiene per se la idoneidad suficiente como para dar inicio a una causa administrativa. En estos casos es necesario que el denunciante manifieste una intención de ser parte en el procedimiento o invoque algún interés o derecho que pudiera verse amagado por un tercero ${ }^{45}$. En este mismo sentido Contraloría General, ha señalado que en el ámbito del procedimiento sancionatorio regulado en la ley No 20.529, el denunciante debe ser calificado, esto es, se exige que tenga un interés directo en el asunto a resolver ${ }^{46}$.

41 Dictámenes Nos 6.190 , de 2014 y 4.547, de 2015. Un estudio más detallado sobre la legitimación del denunciante en materia ambiental se puede ver en HunTer (2019).

42 Dictámenes Nos 34.820, de 2011 y 5.853, de 2013. Por su parte, el artículo 24, No 1 de la Ley No 21.000, de 2017 dispone que el fiscal deberá instruir, respecto de aquellos hechos sobre los que hubiere tomado conocimiento por medio de la denuncia de particulares realizada ante la Comisión, en virtud de aquellos antecedentes que hubiere reunido, las investigaciones que estime procedentes para comprobar las infracciones a las leyes y normativa cuya fiscalización corresponda a la Comisión. En caso de que decida no iniciar la investigación de hechos puestos en su conocimiento, emitirá un informe fundado de las razones para tal decisión, el que deberá ser remitido al Consejo y a los interesados.

$43 \mathrm{Al}$ respecto, la Contraloría ha manifestado que los órganos de la Administración del Estado, en conformidad a los artículos $3^{\circ}, 5^{\circ}$ y $8^{\circ}$ de la LEY No 18.575 de 1986, se encuentran en el imperativo de actuar con la debida eficiencia y rapidez en el cumplimiento de sus funciones y, en particular, de responder las solicitudes que se le formulen en el ámbito de su competencia, véase DiCTAMEN No 61.053, de 2011.

44 Ámbito en el cual la denuncia se encuentra regulada en los artículos 57 y ss. de la LeY No 20.529 de 2011.

45 Rowlands CON SUPERINTENDENCIA DE EDUCACIÓN ESCOLAR (2020) c. 4º. En concreto, la Corte Suprema considera que el afectado por la resolución del Superintendente de Educación es el sostenedor sancionado, excluyendo, por tanto, de la calidad de afectado al denunciante (c. $\left.3^{\circ}\right)$. Al respecto, Nieto sostiene que "Es el interés legítimo y no la presentación de una denuncia lo que atribuye la legitimación procesal, el denunciante suele ser titular de un interés legítimo, pero no necesariamente ya que hay interesados que no presentan denuncias (y que luego pretenden intervenir en el procedimiento) y, a la inversa, hay denunciantes que carecen de interés legítimo y, por consiguiente, de legitimación”, NieTO (2012) p. 113.

46 Dictamen No E40322, de 2020. Al efecto, precisa que en este régimen sancionador es necesario que los denunciantes tengan un interés directo en el asunto que se denuncia, interés que debe ser debidamente ponderado y calificado por el organismo encargado de admitir a trámite la pertinente denuncia. Ahora bien, dicho dictamen agrega que, si la denuncia es admitida a tramitación, le asiste al denunciante el derecho a impetrar en contra de la correspondiente resolución de término, los recursos allí aludidos, con la finalidad, precisamente, de velar por sus intereses. 
En definitiva, la participación de estos terceros interesados mediante denuncia solo tiene por objeto poner en conocimiento de la Administración una conducta irregular (notitia infractionis), sin que ello habilite al tercero a ser parte en el procedimiento o le permita deducir algún tipo de reclamación (salvo ley en contrario), por cuanto, carece de legitimación activa ${ }^{47}$. De este modo, la denuncia no es vinculante para la autoridad y ésta solo podrá ponderarla como un antecedente más.

En consecuencia, la actuación del tercero interesado colaborador o simple denunciante se encuentra limitada a la denuncia, sin que sea su pretensión desarrollar otras actuaciones en el eventual procedimiento sancionador que se instruya.

\section{LOS INTERESADOS NO INFRACTORES TITULARES DE DERECHOS O INTERESES INDIVIDUALES O COLECTIVOS. El DENOMINADO “INTERESADO-VÍCTIMA"}

Se trata de un interesado titular de derechos o intereses individuales o colectivos, que en alguna medida estima que, a través de la instrucción de un procedimiento sancionatorio, podrá protegerlos o garantizarlos ${ }^{48}$. Se trata de interesados que en alguna u otra medida han sido afectados por la ocurrencia de la infracción, como ocurre con un consumidor afectado por un producto defectuoso; con el comerciante que perdió sus productos por una interrupción del suministro eléctrico; con el que ha sufrido una intoxicación por ingerir un alimento en mal estado o con los sujetos que invierten en un mercado de valores en donde la información ha sido falseada, entre otros. En otros términos, estamos ante un interesado "cualificado", que podría actuar válidamente en el procedimiento ${ }^{49}$. Su intervención se puede concretar mediante denuncias o solicitando al órgano respectivo su intervención en un procedimiento sancionatorio en curso ${ }^{50}$.

En estos casos, no cabe duda de que, como consecuencia de un ilícito, terceros pueden ver menoscabados sus derechos o afectados sus intereses. Sin embargo, cabe determinar si el procedimiento administrativo sancionador es la vía idónea para la protección y garantía de los mismos.

\footnotetext{
47 Sobre el particular, el Tribunal Supremo español ha señalado como regla general que el denunciante, por el simple hecho de su denuncia, no tiene interés legitimador para exigir la imposición de sanciones sean pecuniarias o de otro tipo (Por ej. Sentencia Tribunal Supremo, 18 de mayo de 2001). La condición de denunciante, únicamente y por sí misma, no se deriva legitimación para impugnar la resolución que pone fin al procedimiento sancionador, pues el concepto de denunciante no es coincidente con el de parte interesada o titularidad de un derecho o interés legítimo (p. ej. SENTENCIA TRIBUNAL SUPREMo, 16 de marzo de 1982 y 28 de noviembre de 1983). En Chile se puede ver MEDEIROS SOUX CON SEC (2018a) c. $4^{\circ}$ y ss.

48 Se trataría de un "interés legítimo", equivalente a una titularidad potencial de una posición de ventaja o de una utilidad jurídica por parte de quien ejercita la pretensión y que se materializaría de prosperar ésta. La relación entre el sujeto y el objeto de la pretensión comporta que la anulación del acto que se recurre, sea en vía administrativa o jurisdiccional, produzca de modo inmediato un efecto positivo (ventaja) o negativo (perjuicio), actual o futuro para el interesado, en GARCía (2017) p. 93.

49 La cualificación de este denunciante surge de la traslación del concepto de interesado del procedimiento administrativo general al ámbito sancionador. De este modo, el denunciante será considerado como parte interesada cuando su situación jurídica encaje con alguno de los supuestos del artículo 21 de la LEY No 19.880 de 2003, esto es, cuando ostente algún interés legítimo o algún derecho pueda resultar afectado con la resolución que se adopte, véase a Tola (1999) pp. 842-843.

50 Por ejemplo Comunidad Indígena AtaCameña de PeINe con SMA (2019).
} 
En primer término, habrá que revisar lo dispuesto en la legislación general. En tal sentido, por ejemplo, el artículo 38 de la Ley No 1.437, de 2011, de Colombia, por la cual se expide el Código de Procedimiento Administrativo y de lo Contencioso Administrativo, señala que los terceros podrán intervenir en las actuaciones administrativas con los mismos derechos, deberes y responsabilidades de quienes son parte interesada: i) cuando hayan promovido la actuación administrativa sancionatoria en calidad de denunciantes; ii) resulten afectados con la conducta por la cual se adelanta la investigación; o iii) estén en capacidad de aportar pruebas que contribuyan a dilucidar los hechos materia de la misma.

Sin embargo, en Chile no existe una disposición semejante, por lo que resulta necesario estar al texto expuesto en la regulación sectorial respectiva, para determinar la legitimación activa del denunciante y el nivel de participación que tendrá dentro del procedimiento administrativo sancionador en caso de que éste se instruya, incluyendo la posibilidad de impugnar el acto administrativo terminal. En este sentido, el artículo 164 del Código Tributario señala que el denunciante no será considerado como parte ni tendrá derecho alguno debido a su denuncia, la que se tramitará con arreglo al procedimiento que corresponda. En tanto, el artículo 40 de la Ley No 21.000, señala que el procedimiento sancionatorio seguido ante la Comisión admitirá la participación de interesados -en los términos señalados en el artículo 21 de la Ley No 19.880-, con las facultades para aducir alegaciones y aportar documentos u otros elementos de juicio durante toda su tramitación.

Con todo, uno de los ámbitos que ha presentado una mayor regulación y discusión jurisprudencial ha sido el ambiental. El artículo 21 de la Ley No 20.417, establece que, si producto de la denuncia se iniciare un procedimiento administrativo sancionador, el denunciante tendrá para todos los efectos legales la calidad de interesado, disposición que debe ser complementada con lo establecido en el artículo 17 No 3 de la Ley No 20.600, que se refiere a la competencia de los tribunales ambientales para conocer de las reclamaciones en contra de las resoluciones de la SMA ${ }^{51}$. Como primera consecuencia de ello, los denunciantes estarán legitimados para exigir el control jurisdiccional de la resolución que determine no instruir el procedimiento administrativo sancionador y disponga el archivo de la denuncia y de sus antecedentes ${ }^{52}$ así como del acto que apruebe un plan de cumplimiento presentado por el infractor ${ }^{53}$ o la que imponga una sanción ${ }^{54}$. En otros términos, estarán habilitados para recurrir la decisión en la medida que tenga la legitimación activa que exige la acción de

51 Lo que incluye la aportación de prueba, RVC INMOBILIARIA SPA CON SMA (2016), c. 7o.

52 Federación de Sindicatos de Trabajadores Independientes, Pescadores ARtesanales y BuZos Mariscadores I REGIÓN Y OTROS CON DE LA SMA (2014) c. 19 y SEPÚLVEDA Y OTRO CON SMA (2018) c. 19º.

53 Véase PASTENE CON SMA (2018) cc. 25 y ss. Según la Corte, “[...] resulta inadmisible que solo el sujeto pasivo del procedimiento sancionatorio pueda impugnar la resolución que aprueba un programa de cumplimiento, impidiendo que aquellas personas que presentan la denuncia que da inicio al procedimiento administrativo, incluso a los terceros a quienes se les reconozca la calidad de parte interesada, puedan incoar legítimamente las vías jurisdiccionales previstas por la legislación para controlar los actos de la administración, restringiendo el derecho de aquellos a obtener una tutela judicial efectiva en relación a sus derechos que, eventualmente, pueden verse afectados por la aprobación de un instrumento de incentivo al cumplimiento, al margen de la ley.". En un fallo anterior, la Corte Suprema sostuvo que el acto que aprueba un plan de cumplimiento es un acto trámite que "[...] no implica resolver el fondo del asunto controvertido, esto es, sobre la existencia o no de una infracción a la normativa ambiental. Por el contrario, ella busca primeramente que el sumariado cumpla la normativa ambiental ajustando sus operaciones a los nuevos parámetros que él ofrece y que se compromete a respetar, y solo secundariamente, continuar con el procedimiento sancionatorio.”, por lo que no procede impugnación en su contra, en STIPICIC CON SMA (2018) c. 11.

54 Por ej. CRUZ PÉREZ Y OTROS CON SMA (2014) c. 10 y ss. 
nulidad, esto es, que sean lesionados o afectados en sus intereses o derechos legítimos ${ }^{55}$. Esta acción constituye un importante mecanismo de control al eventual ejercicio arbitrario del principio de oportunidad, archivo de los antecedentes y acto sancionatorio.

Ahora bien, el principal problema se presenta en aquellos sectores en los cuales la ley no ha regulado de manera expresa la intervención de los terceros ni su rol dentro del procedimiento sancionador. Al efecto, si bien cabe la aplicación supletoria de la Ley No 19.880, es preciso analizar si lo dispuesto en su artículo 21 es conciliable con la naturaleza de los procedimientos administrativos sancionatorios, siendo necesario atender al fin perseguido en dichos procedimientos ${ }^{56}$.

En este sentido, cabe tener presente que la jurisprudencia administrativa ha precisado que la aplicación supletoria de la Ley No 19.880 procede en cuanto ella sea conciliable con la naturaleza del procedimiento especial, pues su objetivo es solucionar los vacíos que éste presente, sin que pueda afectar o entorpecer el normal desarrollo de las etapas y mecanismos que dicho procedimiento contempla para el cumplimiento de la finalidad particular que la ley le asigna ${ }^{57}$.

Por consiguiente, antes de proceder a la aplicación supletoria del referido artículo 21, será necesario tener presente que:

$1^{\circ}$ En nuestro ordenamiento es el legislador el que determina la legitimación activa para incoar procesos administrativos específicos, descartando la idea de un contencioso administrativo objetivo o respecto del acto administrativo ${ }^{58}$.

$2^{\circ} \mathrm{El}$ procedimiento sancionador tiene una naturaleza represiva la cual corresponde a una reacción frente a la comisión de una infracción que lesiona "intereses supraindividuales” (y no particulares), cuya sanción supone infligir un mal al responsable sin que a través de ello se busque beneficiar a un tercero (al menos no directamente). En otros términos, el procedimiento sancionador presenta una estructura unidireccional con el objeto de verifi-

55 Solo aquellos denunciantes que tengan la calidad de “interesados" podrán impugnar la decisión ante los tribunales. En tal sentido, Ramón Parada ha señalado que podrá desestimarse la reclamación judicial deducida en aquellos "[...] supuestos en que el denunciante no tiene ninguna otra vinculación con los hechos que el de su conocimiento, ni otro interés que el de cumplir en abstracto con su deber de colaboración ciudadana; pero la solución no debe ser la misma cuando, además de que se instruya o no el procedimiento y de que se resuelva en uno u otro sentido, se deriven para él beneficios concretos, como las primas de denuncia, o la prevención de daños para el denunciante o su entorno, como pudiera entenderse en el caso de denuncia de conductas que perjudican como puede ser el caso de denuncia de infracciones urbanísticas", en PARADA (1993) p. 279. En Chile Ferrada sostiene que el "interés legítimo" es clave en los procesos contencioso-administrativos, FerradA (2013) p. 169. Por su parte, en materia ambiental, Hunter ha señalado que "[...] la calidad de interesado en el procedimiento administrativo sancionador que asume el denunciante por la aplicación del artículo 21 LOSMA, es suficiente para legitimar una reclamación ante los TTAA, siempre y cuando se trate de la defensa de un interés legítimo individual, colectivo e incluso el puro interés en el cumplimiento de la legalidad. Sin embargo, esta norma es derrotable (o debe ser interpretada restrictivamente si se quiere), en la medida que se justifique que el denunciante no persigue la tutela de su interés, sino de otros secundarios o espurios, no pudiendo, en consecuencia, considerarse un interesado". HUNTER (2019) p. 176.

56 Cordero (2015) p. 354.

57 Dictámenes №s 86.712, de 2015; 15.331, de 2018; 17.793, de 2019, entre otros. Con ello, la jurisprudencia administrativa ha hecho aplicable una especie de "test" que involucra la naturaleza y propósito del procedimiento especial, en Lara y Helfmann (2015) p. 2015.

58 FERRADA (2013) p. 175. 
car la existencia o no de una infracción administrativa y su sanción. Por ello y no obstante la intervención de terceros, su naturaleza jurídica sigue siendo la misma, esto es, un procedimiento sancionatorio no mutando a otro de carácter no contravencional59.

$3^{\circ}$ Los principios de legalidad y seguridad jurídica exigen un alto grado de previsibilidad y certeza en materia sancionatoria, de ahí la necesidad de una norma que de manera expresa reconozca la intervención de los terceros interesados asignándoles un rol dentro del procedimiento e identificando las acciones jurídicas de que disponen. Por ello cuando el legislador ha querido reconocer la participación de estos terceros interesados en un procedimiento sancionador lo ha señalado expresamente, como ocurre en materia ambiental y de mercado financiero.

$4^{\circ} \mathrm{La}$ intervención no regulada e ilimitada de los terceros interesados podría dilatar indebidamente los procedimientos sancionatorios, entorpecer la investigación ${ }^{60} \mathrm{o}$ inclusive llegar a configurar supuestos de caducidad ${ }^{61}$.

$5^{\circ}$ Por último, no se debe olvidar que el procedimiento sancionador tiene por objeto materializar la pretensión punitiva de la Administración, pero garantizando los derechos y garantías del inculpado, como el derecho a un justo y racional procedimiento, a ser oído, a presentar sus descargos y pruebas y a impugnar la actuación de la Administración, garantías que, sin una adecuada regulación, se podrían ver conculcadas con la intervención casuística de terceros interesados.

No obstante, el tercero interesado titular de derechos o intereses individuales o colectivos, dispone de diversos mecanismos para la garantía de los mismos, por lo que es necesario revisar las acciones y recursos que nuestro ordenamiento jurídico contempla para su protección.

\section{SOBRE LAS MEDIDAS, ACCIONES Y RECURSOS QUE PUEDEN EJERCER LOS TERCEROS INTERESADOS-VÍCTIMA}

No obstante, lo señalado en el apartado anterior, los terceros no infractores titulares de derechos e intereses individuales o colectivos pueden intervenir en los procedimientos sancionatorios mediante denuncias, presentación de antecedentes o a través del ejercicio de acciones específicas contempladas en ciertos ámbitos sancionadores especiales o en la regulación general, como se dará cuenta a continuación.

\section{LA POSIBILIDAD DE DEDUCIR DENUNCIA Y DE ACOMPAÑAR ANTECEDENTES}

Los terceros interesados siempre podrán deducir denuncia, y solicitar a la Administración la adopción de las medidas que estimen oportunas para la garantía de sus derechos

59 Comunidad Indf́gena AtaCAmeña de PeINE CON SMA (2019) c. 47o.

60 Por ej. en materia de mercado financiero la ley admite expresamente la participación de interesados, pero establece un "deber de reserva", señalando que los interesados que se hubieren apersonado en un procedimiento sancionatorio estarán obligados a guardar reserva respecto de la información a la cual accedan durante su tramitación, y no podrán divulgarla a terceros. Dicha reserva se mantendrá aún finalizado el correspondiente procedimiento respecto de la información que no adquiera el carácter de pública en los términos de la Ley No 20.285. La misma norma agrega que la infracción a este deber será sancionado penalmente (reclusión menor en sus grados mínimo a medio y multa de 6 a 10 UTM), artículo 43 de la Ley No 21.000.

${ }^{61}$ Así, por lo demás lo ha considerado la Superintendencia de Educación. 
e intereses. Junto con ello podrán acompañar todos los antecedentes que consideren necesarios para sustentar los hechos que denuncia.

Recibida la denuncia, surge para la Administración el deber de informar los resultados de la denuncia, aun cuando no exista norma que expresamente lo disponga ${ }^{62}$.

\section{PODRÁ INTERVENIR EN EL PROCEDIMIENTO ADMINISTRATIVO SANCIONADOR EN LA MEDIDA QUE TENGA LEGITIMACIÓN ACTIVA \\ El tercero no infractor podrá intervenir en el procedimiento sancionatorio en la me-} dida que tenga legitimación activa, esto es, un interés actual para participar en él y/o, en su caso, para ejercer las eventuales acciones de reclamación contra el acto sancionatorio. Sobre el particular, la Corte de Apelaciones de Santiago ha señalado que "[...] la legitimación activa es un requisito que debe satisfacer quien acude a sede jurisdiccional para obtener lo pretendido, que debe fundarse en un derecho subjetivo y/o interés jurídico actualmente comprometido, y no es un interés simple en velar por la legalidad objetiva, mecanismo que solo es procedente frente a una manifestación de voluntad excepcional y expresa del legislador"63.

\section{SOLICITAR LA REPARACIÓN DE DAÑOS EN LA INSTANCIA ADMINISTRATIVA}

En nuestro ordenamiento no existe una norma que con carácter general establezca la posibilidad de obtener una reparación de daños dentro de un procedimiento administrativo sancionador ${ }^{64}$, por lo que será necesario analizar los medios que pueden ser utilizados para alcanzar esa reparación.

\footnotetext{
${ }^{62}$ Recordemos que la SMA tiene que informar dentro del plazo de 60 días, los resultados de una denuncia por el incumplimiento de instrumentos de gestión ambiental y normas ambientales. Este plazo debe entenderse referido al término dentro del cual procede dar cuenta al denunciante acerca de la medida adoptada respecto de la denuncia recibida, esto es, el inicio de una investigación, la instrucción de un proceso sancionatorio o su archivo, en DICTÁmenes No 4.547, de 2015 y 4.861, de 2019. En otros casos, la Contraloría ha señalado que la solicitud del recurrente en orden a que se fiscalice una situación denunciada y a que se le informe del resultado de dicha actuación, constituye una manifestación del derecho de petición, garantizado en el artículo 19 № 14, de la Constitución, el que conlleva la obligación de los organismos que integran la Administración del Estado de responder las solicitudes que le formulan los interesados, tomar una determinación frente a lo pedido y dar a conocer la respuesta por escrito al peticionario. También hizo presente que, conforme con el artículo $8^{\circ}$ de la Ley No 18.575, su actuación puede tener lugar por propia iniciativa en el cumplimiento de sus funciones, o a petición de parte cuando la ley lo exija expresamente o se haga uso del derecho de petición o reclamo, procurando la simplificación y rapidez de los tramites, en DICTAMEN No 4.560, de 2019.

${ }^{63}$ Medeiros Soux CON SEC (2018a). En este fallo, además, la Corte de Apelaciones sostuvo que "Séptimo: [...] no consta si el reclamante tiene la calidad de afectado, toda vez que no se acreditó cuál sería su interés actual o derecho comprometido que hubiese sido afectado y que pudiese en cierta medida habilitarlo como titular para reclamar en los términos del artículo 19 de la Ley en comento, sumado a que no existe en esta materia una acción popular en el mero interés público. Tanto es así, que el proceso administrativo sustentado por la Superintendencia de Electricidad y Combustibles fue incoado contra la Empresa ENEL CHILE, fijándose entre ambos la relación jurídico-administrativa cuyos efectos y consecuencias se vinculan entre ambos, no así al recurrente señor Madeiras. A mayor abundamiento, tampoco consta si el reclamante tuviese la calidad de consumidor, ya sea de alta o baja tensión, si es un cliente libre o regulado." Este fallo fue confirmado por la Corte Suprema MEDEIROS SOUX CON SEC (2018b). Esta decisión sigue el criterio contenido en CONADECUS CON SEC (2017).

${ }^{6}$ En Perú la reparación del daño ha sido considerada como una eximente de responsabilidad. La norma establece que la subsanación voluntaria por parte del posible sancionado del acto u omisión imputado como constitutivo de infracción administrativa, con anterioridad a la notificación de la imputación de cargos, constituyen
} 
Al respecto, el artículo 177 del Código Sanitario, señala que cuando se trate de una primera infracción y aparecieren antecedentes que lo justifiquen, la autoridad sanitaria podrá “[...] apercibir y amonestar al infractor, sin aplicar la multa y demás sanciones, exigiendo que se subsanen los defectos que dieron origen a la infracción, dentro del plazo que se señale" ${ }^{35}$, lo que permitiría incluir la reparación de los daños causado al interesado víctima de la infracción.

Asimismo, el artículo 42 de la Ley No 20.417 dispone que, una vez iniciado un procedimiento sancionatorio, el infractor podrá presentar en el plazo de 10 días, contado desde el acto que lo incoa, un programa de cumplimiento, en el cual se indiquen las acciones y metas, las que pueden contener acciones de reparación de daños. El plan deberá ser aprobado por la SMA fijando un plazo para que los responsables cumplan satisfactoriamente con la normativa ambiental que se indique.

Otra forma, es configurar la reparación de los daños como una circunstancia atenuante de responsabilidad que puede utilizar la Administración para determinar el rango y el monto específico de las sanciones. Por ejemplo, el artículo 26 inciso $2^{\circ}$ letra c) de la Ley No 18.755 , señala que para la definición de la cuantía de la multa se podrá considerar las providencias que se hubieren tomado para reducir los daños. Con todo, es posible estimar que aun cuando no exista norma que lo disponga expresamente, la reparación del daño ocasionado por la infracción podría ser considerada por la Administración como una atenuante de la responsabilidad para el infractor ${ }^{66}$.

Por su parte, en materia educacional, se utilizan ambas figuras, al señalar que la subsanación de infracciones leves no será sancionada y que la subsanación de los incumplimientos reportados será considerada como circunstancia atenuante de responsabilidad. En ambos supuestos, la subsanación puede contener la reparación del daño ocasionado al interesado-víctima ${ }^{67}$.

En todos estos casos, el problema radica en que la ley entrega al sujeto infractor las acciones de reparación de los daños, proporcionando diversos incentivos para su concreción, limitando la participación de terceros interesados. Por ello, en España se entrega al órgano que corresponde el ejercicio de la potestad sancionadora la determinación y exigibilidad de las indemnizaciones por los daños y perjuicios causados ${ }^{68}$, lo cual permitiría una mayor intervención de los terceros interesados por cuanto, la responsabilidad infraccional

condiciones eximentes de la responsabilidad por infracciones, véase artículo 236-A No 1, letra f) del Decreto Legislativo No 1272, que modifica la LeY No 27.444 de 2001, de Procedimiento Administrativo General y que deroga la LEY No 29.060 de 2007, Ley del Silencio Administrativo.

65 Para Contraloría este precepto tiene un carácter discrecional, y agrega que para la determinación del plazo allí indicado, la autoridad deberá otorgar uno que, conforme a criterios de justicia y razonabilidad, permita al infractor reparar la inobservancia reprochada, véase los DiCTÁmenes $\mathrm{N}^{\text {os }} 9.759$, de 2013 y 26.773 , de 2016.

66 Constructora larraín Prieto Risopatrón S.A. con SEC (2004) c. $6^{\circ}$.

67 Artículos 78 inciso 2o y 79 letra a) LEY No 20.529.

68 Así lo ha previsto la Ley No 40 de 2015, de 1 de octubre, de Régimen Jurídico del Sector Público, al señalar en su artículo 28.2, relativo al principio de responsabilidad en materia administrativa sancionadora que "Las responsabilidades administrativas que se deriven de la comisión de una infracción serán compatibles con la exigencia al infractor de la reposición de la situación alterada por el mismo a su estado originario, así como con la indemnización por los daños y perjuicios causados, que será determinada y exigida por el órgano al que corres- 
que en aquél se establezca, se encuentra vinculada al reconocimiento de los daños ocasionados por el ilícito y, con ello, a la obtención de una indemnización por los perjuicios que aquél le ha ocasionado ${ }^{69}$.

\section{LAS ACCIONES O RECURSOS CONEXOS}

Como ya se ha indicado, uno de los principales objetivos de la intervención del interesado-víctima en el procedimiento sancionatorio, es lograr la protección de sus derechos e intereses, pero no necesariamente la instrucción y resolución del mismo podrá resguardarlos. Por ello, resulta necesario recurrir a las acciones y recursos que le proporciona el ordenamiento jurídico para la garantía de los mismos.

a) Acciones constitucionales de protección o amparo: dada su naturaleza, estas acciones constitucionales podrán ser deducidas por los titulares de derechos subjetivos garantizados por la Carta Fundamental, que hayan sido o sean vulnerados por una actuación u omisión ilegal constitutiva de una infracción administrativa ${ }^{70}$.

b) Acciones de reparación de perjuicios, en tal sentido, si bien algunos autores han criticado esta circunstancia dado que confunde la finalidad punitiva y la reparadora, la sanción no debe ser un obstáculo a las medidas reparatorias civiles ${ }^{71}$. Así, por ejemplo, en materia ambiental la aplicación de sanciones es compatible con las acciones de reparación de daño ambiental (artículo 17 No 2 de la Ley No 20.600) y de indemnización de perjuicios por la producción de daño ambiental (artículo 46 de la Ley No 20.600).

Ahora bien, en estos procesos, será una importante pieza probatoria, acompañar la resolución que resuelve el procedimiento administrativo sancionador, particularmente cuando se ha impuesto una sanción al infractor. Recordemos que tanto el expediente como el acto administrativo que sanciona constituyen medios de prueba, dado su carácter de instrumento público ${ }^{72}$.

c) Las acciones de protección de los derechos de consumidores: en este sentido, el artículo 51 de la Ley No 19.496, señala que cuando se vea afectado el interés colectivo o difuso de los consumidores, se podrá deducir el procedimiento especial que allí se detalla, en el cual la prueba se apreciará de acuerdo con las reglas de la sana crítica. Este supuesto podrá tener lugar en aquellos casos en los que, como consecuencia de una infracción administrativa, resulten vulnerados los derechos de los consumidores, como sería con la ocurrencia de una infracción al sistema financiero ${ }^{73}$.

d) Las acciones penales: diversas son las leyes que disponen que la infracción a sus preceptos podrá dar lugar a responsabilidad administrativa y penal, como ocurre en

ponda el ejercicio de la potestad sancionadora”. Disposición que no ha estado exenta de críticas, al efecto véase a Huergo (2016) pp. 399-411.

69 SENTENCIA TRIBUNAL SUPREMO (2006).

70 CHAHUÁN Y OTROS CON ENAP REFINERÍAS S.A. Y OTRAS (2019).

71 Moderne (1993) pp. 88 y ss.

72 Bielsa (1964) pp. 80-81.

73 Bajo este supuesto se tramitó la demanda colectiva contra La Polar en 2011, véase: https://www.sernac.cl/ portal/604/articles-3028_archivo_02.pdf. 
materia de mercado de valores ${ }^{74}$. A través de este tipo de acciones, se pueden buscar distintos intereses, inclusive aquellos de índole moral ${ }^{75}$.

\section{EFECTOS DE LA INTERVENCIÓN DE TERCEROS EN EL PROCEDIMIENTO ADMINISTRATIVO SANCIONADOR}

\section{LA INTERVENCIÓN DE TERCEROS, LOS DERECHOS DEL INFRACTOR Y LOS FINES DE INTERÉS GENERAL}

\section{a) La afectación del derecho a un justo y racional procedimiento}

La intervención en un procedimiento sancionador de una multiplicidad de terceros, cada uno alegando diversos derechos e intereses, podría llegar a afectar el derecho a la defensa del inculpado, el que no solo deberá defenderse de la acusación fiscal, sino que también de las cuestiones planteadas por los terceros interesados y que no necesariamente serán consistentes con la naturaleza sancionadora del procedimiento.

De ahí la exigencia de una norma que regule su intervención, ello con el objeto de armonizar los diversos intereses y derechos concurrentes. En este sentido, sería interesante la fijación de algunas cuestiones mínimas para la intervención de terceros como sería establecer ciertos requisitos básicos para su comparecencia o que, en los casos de pluralidad de interesados, el infractor pueda solicitar la unificación de alegaciones, disponiéndose de una audiencia o instancia especial para la presentación de pruebas o recopilación de antecedentes.

\section{b) Afectación al principio de objetividad}

Otrora, el artículo 82 del Reglamento de sello y timbre de 1886 de España, disponía que "Las condonaciones parciales, que [...] pueda otorgar el Ministerio de Hacienda, no alcanzará nunca a la tercera parte que corresponde a los inspectores, investigadores o denunciadores". Respecto de dicha norma, García de Enterría y Fernández señalaron que la regulación que permite la participación de los denunciantes en la sanción y que los convierte en interesados en el procedimiento punitivo, infringe los principios sustanciales de objetividad en la actuación sancionadora ${ }^{76}$. Esta exigencia de objetividad en la imposición

\footnotetext{
74 Por ej. artículo 63 inciso final de la LEY No 18.045 de 1981. Aunque en otros casos la posibilidad de accionar por la vía penal está entregada a la Administración, lo cual puede dar lugar a cuestionamientos relativos a los límites a discrecionalidad de que dispone para adoptar dicha decisión, DICTAMEN No 14.000, de 2017.

75 Administrativamente se ha negado la legitimación del denunciante cuando se invoca un mero interés moral, véase Sentencia TRibunal Supremo, 26 de noviembre de 2002 y Sentencia Tribunal Supremo, 22 de mayo de 2007. El mismo tribunal ha sostenido que el interés, en su faceta positiva o negativa (supresión de una carga o desventaja) no puede identificarse con el interés moral o la satisfacción personal o espiritual del afectado. El mero interés moral de que se sancione al denunciado no es suficiente para fundamentar su legitimación. Véase Sentencia TRibunal SupRemo, 26 de noviembre de 2002; SEnTENCIA TRIBUnal SupRemo, 22 de mayo de 2007 y Sentencia Tribunal Supremo, 3 de febrero de 2011, entre otras. Junto con ello, se ha sostenido que el interés moral del denunciante perjudicado por una infracción no le confiere legitimación para recurrir la sanción impuesta ante los tribunales contencioso-administrativos y solicitar una sanción mayor, SENTENCIA TRIBUNAL SUPREMO, 28 de enero de 2019.

76 García y Fernández (2011) Tomo II, pp. 210 y ss.
} 
de la sanción llevó a la jurisprudencia a negar la condición de parte interesada al denunciante de la infracción ${ }^{77}$, y terminó por imponerse en materia tributaria, suprimiendo el carácter de interesado del denunciante en el procedimiento sancionador y su participación en las multas ${ }^{78}$.

A la data, en Chile no existen disposiciones similares ${ }^{79}$, sin embargo, la exigencia de objetividad ha sido puesta de relieve por el Tribunal Constitucional en el caso SERNAC ${ }^{80}$, en el cual se sostuvo que los poderes que se venían atribuyendo a dicho servicio, le restaban imparcialidad, ya que aquel órgano estaría representando los intereses de una de las partes involucradas en el procedimiento.

Esta misma observación se puede realizar respecto del sancionatorio laboral, en donde el respeto por la normativa laboral y la defensa de los derechos e intereses particulares de los trabajadores se mueve en un ámbito sumamente difuso, en donde, en muchas ocasiones, no resulta fácil distinguir la pretensión estatal de la de los trabajadores.

Ahora bien, en términos generales la Ley No 19.880 impone a los órganos administrativos el deber de actuar con objetividad (artículo 11), exigencia que deberá respetar la Administración en todo momento, sea que participen o no terceros interesados en el procedimiento sancionador.

\section{c) Afectación a los fines de interés general que persigue la Administración}

La intervención de terceros no infractores puede, ciertamente, no coincidir con los fines de interés general que la Administración busca satisfacer, como la protección del medio ambiente, del mercado financiero, la salubridad pública, la continuidad de la educación o la seguridad del suministro eléctrico. Sin embargo, los intereses de los terceros no infractores pueden ser múltiples, desde aquellos que buscan la reparación de los daños hasta aquellos que solo atienden a una satisfacción moral. Con todo, la actividad sancionadora de la Administración no tiene por finalidad satisfacer la pretensión directa del interesado que se encuentra envuelta en la denuncia o en su posterior intervención en el procedimiento, ni puede reestablecer el imperio del derecho, lo cual es propio de los tribunales de justicia. Además, la intervención puede dilatar el procedimiento sancionador afectando el efecto disuasivo de la sanción, llegando inclusive a generar situaciones de prescripción o caducidad del procedimiento.

\section{LA INTERVENCIÓN DE TERCEROS COMO HERRAMIENTA DE COLABORACIÓN Y CONTROL}

Finalmente, cabe destacar algunos factores relevantes que presenta la intervención de los terceros interesados no infractores en los procedimientos sancionadores.

\footnotetext{
77 Sentencia Tribunal Supremo, 16 de marzo de 1982 y Sentencia Tribunal Supremo, 27 de junio de 1985.

78 LozANo (1990) pp. 187 y ss.

79 Históricamente, el denunciante podía obtener parte del precio de la venta de ciertos objetos decomisados, en Huneeus (1880) 114-155. Con todo, mediante Boletín No 13.111-03, Moción de un grupo de Diputados, se busca modificar diversos cuerpos legales para establecer un incentivo económico a favor del denunciante en los delitos de colusión y aquellos que acarrean responsabilidad penal de las personas jurídicas.

80 Control de constitucionalidad, Ley No 19.496, Rol 4012-17 (2018).
} 
En primer lugar, su participación constituye un mecanismo de control a un eventual ejercicio ilegal o arbitrario de la potestad sancionadora, en otros términos, permitiría limitar la discrecionalidad de que dispone la Administración al iniciar el procedimiento, al adoptar medidas provisionales, al imponer una sanción o al ejecutar la misma.

Junto con ello, la intervención de terceros promueve la transparencia y publicidad de las actuaciones, elevando el estándar de motivación de los actos administrativos, y se constituyen en verdaderos colaboradores con la labor de fiscalización que debe practicar la Administración.

\section{CONCLUSIONES}

La situación jurídica en la cual se encuentran los interesados no infractores en los procedimientos administrativos sancionadores no es un tema pacífico. Ello, fundamentalmente, por la ausencia de reglas claras que permitan definir la forma en que aquéllos podrían intervenir en el procedimiento y los efectos de dicha intervención.

En nuestro ordenamiento, si bien procede intervención de terceros interesados en los procedimientos sancionadores por aplicación supletoria del artículo 21 de la Ley No 19.880, ésta se debe efectuar teniendo presente los diversos intereses y derechos concurrentes, ello atendida su naturaleza sancionatoria, a través de la cual se busca reprimir la comisión de una infracción que vulnera bienes jurídicos de carácter supraindividual y cuya sanción no conlleva un beneficio, al menos directo, para los interesados no infractores. Además, se debe considerar que los derechos y garantías constitucionales que han venido siendo reconocidos al infractor en el mismo, puede verse, en ciertos casos, vulnerados con la participación de terceros en el procedimiento.

Como una forma de dar respuesta a esta problemática, es necesario determinar en primer término, el tipo de interesado no infractor de que se trata, esto es, si se trata de un interesado colaborador o simple denunciante o de un interesado-víctima. Enseguida, será preciso establecer cuáles son los intereses y derechos que busca resguardar, determinando si aquéllos pueden o no ser protegidos en la instancia administrativa sancionadora o, en su caso si corresponde utilizar alguna de las acciones o recursos que contempla nuestro ordenamiento jurídico para su protección. Lo anterior es sin perjuicio de las reglas de intervención especial que se dispongan para la participación de interesados no infractores, tal como acontece en materia ambiental.

En definitiva, es preciso analizar esta problemática con una mirada integral, que permita compatibilizar los diversos intereses y derechos concurrentes, esto es, los del infractor, los de los terceros interesados no infractores y, ciertamente, los fines de interés general que persigue la Administración.

\section{BIBLIOGRAFÍA CITADA}

Aldunate, Eduardo (2009): Constitución Politica de la República de Chile, Tomo I (Santiago, Punto Lex).

BAUZÁ, Felio (2015): "Habeas denuncia. Identidad del denunciante en el procedimiento sancionador", Revista General de Derecho Administrativo, No 40: pp. 1-39. 
BERMúdeZ, Jorge (2012): "Discrecionalidad y conceptos jurídicos indeterminados en la actuación de la Administración Pública", Revista de Derecho Administrativo, No 7: pp. 3-26. Bielsa, Rafael (1964): Derecho Administrativo, Tomo II (Buenos Aires, La Ley, 6a edición). Cordero, Eduardo (2014): Derecho Administrativo Sancionador. Bases y principios en el Derecho chileno (Santiago, Legal Publishing).

Huergo, Alejandro (1995): "La desigualdad en la aplicación de potestades administrativas de gravamen: remedios jurídicos”, Revista de Administración Pública, No 137: pp. 189-238.

Huergo, Alejandro (2016): "Sanciones administrativas y responsabilidad civil: ¿puede declarar la Administración la responsabilidad civil frente al perjudicado por la infracción?”, en VV.AA., Homenaje al profesor Luis Martínez Roldán (Oviedo, Ediciones Universidad de Oviedo) pp. 399-411.

Huneeus, Jorge (1880): La Constitución ante el Congreso (Santiago, Imprenta de Los Tiempos).

HunTER, Iván (2019): "La legitimación popular del denunciante en la nueva justicia ante los tribunales ambientales”, Revista de Derecho, No 245: pp. 173-199.

García de Enterría, Eduardo y Fernández, Tomás-Ramón (2011): Curso de Derecho Administrativo, Tomo II (Madrid, Civitas, Thomson Reuters, 12a edición).

García, Francisco (2017): Sanciones administrativas (Granada, Comares, 4a edición).

GosálBeZ, Humberto (2012): "Los interesados en el ejercicio de la potestad administrati-

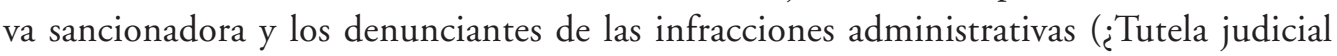
efectiva de las víctimas en la última jurisprudencia contencioso-administrativa?)”, en García de Enterría, Eduardo y Alonso, Ricardo (coord.), Administración y justicia: un análisis jurisprudencial, vol. 1 (Madrid, Civitas) pp. 1389-1436.

FERradA, Juan Carlos (2013): "La legitimación activa en los procesos administrativos anulatorios en el derecho chileno", en Ferrada, Juan Carlos (coord.), La nulidad de los actos administrativos en el derecho chileno (Santiago, Thomson Reuters).

Lara, José Luis y Helfmann, Carolina (2015): Ley de procedimiento administrativo, Tomo I (Santiago, Thomson Reuters, 2a edición).

LozAno, Blanca (2003): "El principio de oficialidad de la acción sancionadora administrativa”, Revista de Administración Pública, No 161: pp. 83-121.

LozANO, Blanca (1990): La extinción de las sanciones administrativas y tributarias (Madrid, Marcial Pons).

Moderne, Franck (1993): Sanctions administratives el justice constitutionnelle (Contribution a Vétudedu jus puniendi de l'Etat dans les démocraties contemporaines) (París, Económica).

Moraga, Claudio (2010): Tratado de Derecho Administrativo. La actividad formal de la administración del Estado, Tomo VII (Santiago, LegalPublishing).

Muñoz Machado, Santiago (dir.) (2017): Diccionario Panhispánico del español jurídico, Vol. I (Madrid, Real Academia Española).

Nogueira, Humberto (2013): Derechos fundamentales y garantías constitucionales, Tomo II (Santiago, Librotecnia, $3^{\text {a }}$ edición).

Parada, Ramón (1993): Régimen Jurídico de las Administraciones Públicas y Procedimiento Administrativo Común (Madrid, Marcial Pons).

Quezada, Flavio (2017): Procedimiento administrativo sancionador en la Ley $N^{o} 19.880$ (Santiago, Librotecnia). 
Rebollo, Manuel (1993): "Interesados y denunciantes en el procedimiento administrativo sancionador", en BARNÉs, Javier (coord.), El procedimiento administrativo en el derecho comparado (Madrid, Civitas) pp. 227-256.

Sepúlveda, Enrique y ZúŇiga, Francisco (2014): “¿Privatización de la potestad sancionadora del Estado? Procedimiento administrativo sancionador y contencioso administrativo a propósito de una novedosa jurisprudencia”, en Arancibia, Jaime y Alarcón, Pablo (coord.), Sanciones Administrativas (Santiago, Thomson Reuters): pp. 690-691.

Tola, Miguel Ángel (1999): "La consideración jurídica del denunciante en el procedimiento sancionador", Actualidad Administrativa No 31: pp. 839-858.

\section{NORMAS CITADAS}

Decreto No 100 (22/9/2005), Fija el texto refundido, coordinado y sistematizado de la Constitución Política de la República de Chile.

DFL No 1.122 (29/10/1981), Código de Aguas.

LEY No 18.010 (27/6/1981), Establece normas para las operaciones de crédito y otras obligaciones de dinero que indica.

Ley No 18.045 (22/10/1981), Ley de Mercado de Valores.

Ley No 18.575 (5/12/1986), Ley Orgánica Constitucional de Bases Generales de la Administración del Estado.

LEY No 19.496 (7/3/1997), Establece normas sobre protección de los derechos de los consumidores.

Ley No 19.696 (12/10/2000), Código Procesal Penal.

Ley No 19.880 (29/5/2003), Bases de los Procedimientos Administrativos que rigen los actos de los Órganos de la Administración del Estado.

LeY No 19.995 (7/1/2005), Establece las Bases Generales para la Autorización, funcionamiento y fiscalización de casinos de juego.

Ley No 20.417 (26/1/2010), Crea el Ministerio, el Servicio de Evaluación Ambiental y la Superintendencia del Medio Ambiente.

LEY No 20.529 (27/8/2011), Sistema Nacional de Aseguramiento de la calidad de la educación parvularia, básica y media y su fiscalización.

Ley No 20.600 (28/6/2012), Crea los Tribunales Ambientales.

Ley No 21.000 (23/2/2017), Crea la Comisión para el Mercado Financiero.

\section{JURISPRUDENCIA CITADA}

JUDICIAL

EXPORTADORA Los Fiordos LIMITADA CON SMA (2017): Corte Suprema, 3 de agosto de 2017 (casación), Rol No 38.340-2016.

ChAHUÁN Y OtRos CON ENAP REFINERÍAS S.A. Y OtRAS (2019): Corte Suprema, 28 de mayo de 2019 (protección), Rol No 5.888-2019.

CONADECUS CON SEC (2017): Corte de Apelaciones de Santiago, 25 de agosto de 2017 (reclamo de ilegalidad), Rol No 9351-2017. 
Constructora Larraín Prieto Risopatrón S.A. con SEC (2004): Corte Suprema, 21 de enero de 2004 (reclamo de ilegalidad), Rol No 5.173-2003.

PASTENE CON SMA (2018): Corte Suprema, 5 de marzo de 2018 (casación), Rol No 11.4852017.

Medeiros Soux con SEC (2018a): Corte de Apelaciones de Santiago, 16 de abril de 2018 (reclamo de ilegalidad), Rol No 14-2018.

MEDEIROS SOUX CON SEC (2018b): Corte Suprema, 11 de junio de 2018 (reclamo de ilegalidad), Rol No 12.188-2018.

URZÚA Y OTROS CON FISCO (2018): 9o Juzgado Civil de Santiago, 24 de agosto de 2018 (acción ordinaria de indemnización de perjuicios), Rol No 17.229-2011.

STIPICIC CON SMA (2018): Corte Suprema, 29 de agosto de 2018 (casación), Rol No 35722018.

Romo con Municipalidad de lo PRADo (2019): Corte Suprema, 28 de enero de 2019 (protección), Rol No 26450-2018.

Rowlands CON SuperintendenCIA de EDUCACIÓN ESCOLAR (2020): Corte Suprema, 27 de enero de 2020 (reclamación), No 32.663-2018.

\section{CONSTITUCIONAL}

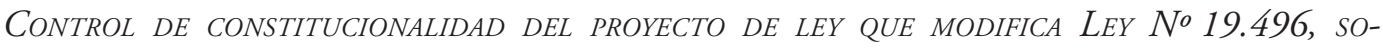
bre Protección de los Derechos de los Consumidores. Correspondiente al boletín No 9369-03 (2018): Tribunal Constitucional, Rol No 4012-2017, 18 de enero de 2018.

\section{AMBIENTAL}

Federación de Sindicatos de Trabajadores Independientes, Pescadores Artesanales y BUzos MARISCADORES I REGIÓN Y OTROS CON DE LA SMA (2014): Segundo Tribunal Ambiental (Santiago), 23 de abril de 2014 (reclamación), R-14-2014.

CRUZ Pérez y otros con SMA (2014): Segundo Tribunal Ambiental (Santiago), 3 de marzo de 2014 (reclamación), R-6-2014 (Acumuladas R-7-2013 y R-8-2013).

Agrícola el Sol de Copiapó Ltda. y otra con SMA (2016): Segundo Tribunal Ambiental (Santiago), 29 de enero de 2016 (reclamación), R-48-2014 (Acumuladas R-49-2014; R-64-2015 y R-65-2015).

CARRASCO CON SMA (2017): Segundo Tribunal Ambiental (Santiago), 28 de junio de 2017 (reclamación), R-116-2014.

RVC INMOBILIARIA SPA CON SMA (2016): Segundo Tribunal Ambiental (Santiago), 15 de noviembre de 2016 (reclamación), R-108-2016.

SEPÚLVEDA Y OTRO CON SMA (2018): Segundo Tribunal Ambiental (Santiago), 22 de julio de 2019 (reclamación), R-177-2018.

Comunidad Indígena Atacameña de Peine con SMA (2019): Primer Tribunal Ambiental (Antofagasta), 26 de diciembre de 2019 (reclamación), R-17-2019 (Ac R-18-2019 R-19-2019). 
Gómez GonzÁlez, Rosa Fernanda "Los interesados en los procedimientos administrativos sancionadores"

\author{
ADMINISTRATIVA \\ Dictamen Contraloría General (1972): No 14.009, 24 de febrero de 1972. \\ DiCTAMEN CONTRALORÍA GENERAL (2004): No 59.940, 3 de diciembre de 2004. \\ Dictamen Contraloría General (2011): No 34.820, 1 de junio de 2011. \\ Dictamen Contraloría GENERAL (2011): No 61.053, 27 de septiembre de 2011. \\ Dictamen Contraloría General (2013): No 5.853, 25 de enero de 2013. \\ Dictamen Contraloría General (2013): No 9.759, 12 de febrero de 2013. \\ Dictamen Contraloría General (2014): No 6.190, 24 de enero de 2014. \\ Dictamen Contraloría General (2015): No 4.547, 16 de enero de 2015. \\ DiCTAMEN CONTRALORÍA GENERAL (2015): No 86.712, 2 de noviembre de 2015. \\ Dictamen Contraloría General (2016): No 26.773, 11 de abril de 2016. \\ Dictamen Contraloría General (2016): No 75.745, 14 de octubre de 2016. \\ Dictamen Contraloría General (2016): No 14.000, 21 de abril de 2017. \\ DiCTAMEN CONTRALORÍA GENERAL (2019): No 4.560, 13 de febrero de 2019. \\ DiCTAMEN CONTRALORÍA GENERAL (2019): No 4.861, 15 de febrero de 2019. \\ Dictamen Contraloría General (2018): No 15.331, 20 de junio de 2018. \\ Dictamen Contraloría General (2019): No 17.793, 2 de julio de 2019. \\ Dictamen Contraloría General (2019): No E40322, 2 de octubre de 2020.
}

JURISPRUDENCIA INTERNACIONAL

Sentencia Tribunal Supremo, 16 de marzo de 1982.

SENTENCIA TRIBUNAL SUPREMO, 28 de noviembre de 1983.

Sentencia Tribunal Supremo, 7 de junio de 1985.

Sentencia Tribunal Supremo, 27 de junio de 1985.

SENTENCIA TRIBUNAL SUPREMo, 18 de mayo de 2001.

Sentencia Tribunal Supremo de Justicia de CANTABRIA, 30 de enero de 2002.

SENTENCIA TRIBUnal Supremo, 26 de noviembre de 2002.

Sentencia Tribunal Supremo, 11 de abril de 2006.

SENTENCIA TRIBUNAL SuPREMo, 11 de abril de 2006.

SENTENCIA TRIbUNAL Supremo, 22 de mayo de 2007.

Sentencia Tribunal Supremo, 10 de diciembre de 2010.

Sentencia Tribunal Supremo, 3 de febrero de 2011.

SENTENCIA TRIBUnal SuPREMo, 28 de enero de 2019.

SENTENCIA TRIBUNAL SuPREMO, 28 de enero de 2019. 